\title{
3 Mapping the Mobile eWorkforce in Europe
}

\author{
Karsten Gareis, Stefan Lilischkis and Alexander Mentrup
}

\section{1 eWork and physical mobility}

Because they enable time-space compression (Harvey 1989), information and communication technologies (ICTs) tend to make human labour less bound to place. They do not, however, automatically lead to a decentralisation of work locations across territory. Neither do they necessarily lead to a friction-less, fully mobile society where workers roam about as free agents and produce the allocation of labour which at any given time and space produces the highest possible added value. While there are examples of persons who have exploited the potential for working at a distance from their central office, and of companies who turn their staff into a mobile workforce in order to get in closer contact to customers, research suggests that the overall relationship between ICTs, location and physical mobility is a highly complex one. Only very seldom do ICT-based structures substitute full-scale for traditional ways of carrying out work. More often, they supplement to and transform existing structures in a way which best accommodates the capitalist imperative as well as the inertia which is a builtin feature of all social systems.

Recent empirical evidence, for example, tells us that telework has in practice developed in ways which have not been expected by the proponents of this type of separation between work location and employer's premises. Telework has not lead to decentralisation of work, but is more likely than not to take place inside of urban agglomerations (Ellen and Hempstead 2002). Teleworkers also show higher rates of work-related geographical mobility than persons in traditional work settings, enabled by mobile office technology, which has liberated work from being bound to a particular space and time (Gareis 2003).

Instead of the home becoming a near-permanent second workplace, we face a situation where much work has become more locationally flexible, and workers settle down temporarily wherever it suits their job, tasks and personal preferences best, all the time staying connected to the networks they need for their work. For many, the home has been turned into a touchdown office, together with a (potentially infinite) number of other locations where work can - and increasingly does - take place. We are calling 
the people who practice this way of working mobile eWorkers. While lifestyle magazines are bristling with futuristic depictions of "anywhere, anytime" work, surprisingly little statistical data exists about the actual size and structure of this section of the EU workforce. Moreover, there is only limited understanding of which workers are most involved in mobile activities. Certainly, ICT-enabled mobility does not affect all workers to the same extent (Valenduc et al. 2000), as is sometimes indicated in futurist depictions. A differentiated view is necessary in order to identify future challenges for social cohesion and the health of the labour market.

To shed some more light on the discussion around ICT-enabled mobility of work, the authors use a database from a recent, representative EU-wide survey (SIBIS ${ }^{1}$ ) to explore in more depth the key characteristics of mobile workers and mobile eWorkers. The findings will allow us to gain a better understanding of the reality of mobile eWork in Europe today.

Before doing so, this chapter will discuss the background against which mobile forms of working are developing. Section two looks at some of the main drivers behind worker mobility in general, and mobile eWork, in particular. This will allow us to relate the phenomenon to more general developments in work organisation and labour markets in the EU and beyond. Section three will then present a conceptual framework for making sense of the interrelations between ICTs, work/task characteristics, and work mobility. This will include discussion of the mobility term itself. Increasingly, there is talk of so-called "virtual mobility", that means relations in which not the workers themselves, but only the "work", that means work inputs, work products, are moving across space, for example inside of value chains. While in this chapter, mobility is always meant as physical mobility unless stated otherwise, we need to always bear in mind that, in times of virtual reality and ambient intelligence, the purposes which have traditionally required physical mobility might increasingly be achieved through electronic means.

1 The SIBIS database stems from population surveys, which were undertaken in 2002/2003 in all current EU25 Member States plus the USA, Switzerland, Romania and Bulgaria. For more information on SIBIS (Statistical Indicators Benchmarking the Information Society), see www.sibis-eu.org. The project was funded by the European Commission through its Information Society Programme. 


\subsection{Drivers}

\subsubsection{Drivers of worker mobility}

The following is a brief discussion of the factors and developments which have been important drivers for increasing the physical mobility of workers in recent decades.

We can distinguish between economic, technological and socio-cultural drivers without neglecting that the three domains are closely interrelated and should not be explored in isolation from each other.

Economic drivers for worker mobility have their origin in the restructuring of western capitalism since the economic crisis of the late 1960s and early 1970s. Via growing interconnectedness of market participants, this trend has lead to an increasing division of work at a global scale (Massey and Megan 1979) and growing market power of multi-national corporations (Dicken 2003). Intra-company transactions which stretch across locations, regions, countries and continents have multiplied. The organisation of the production process has also changed towards greater parts being executed as market transactions instead of intra-organisational movements of goods and information. Collaboration and network-building between independent enterprises have increased. A higher number of employees spend more time collaborating with external parties. All of this has directly resulted in more travel activity, longer distances and more time spent on travelling.

Another outcome of the economic restructuring in the last third of the $20^{\text {th }}$ century has been a sharp increase in competitive pressure. Enterprises have reacted in a number of ways, often by adopting more flexible production systems, whereby flexible transport services have become an integral and essential part of the production process (Gareis 2003). This is, for example, the case with just-in-time production systems, where input deliveries are made in close co-ordination with production schedules, leading to more frequent deliveries of smaller quantities of materials. And just as just-in-time production transfers the warehouse onto the roads to respond more quickly and adequately to changes in demand, mobile eWork transfers work onto the streets so to better respond to the demands of the customer, what the authors have termed "just-in-time-working" before. In a push for enhanced customer orientation, value chains have also been redesigned to take better account of what customers ask for, thereby gaining competitive advantage (Davidow and Malone 1992). In many cases, com- 
panies strive to spend more time and effort on learning what customers want. This implies getting in touch with customers, which (still) means more often than not face-to-face interaction. Physical proximity to great numbers of customers spread over the territory requires mobility.

Recent years have seen much emphasis being put on cost cutting. Because office space is expensive, and rates of utilisation are often shockingly low, because workers are in meetings, visiting customers, teleworking, or on holiday, companies have started to exploit possibilities of distributing office space more effectively, what is called desk-sharing, hoteling or hot desking. There is a growing feeling that reserving personal workspace for the exclusive use of individual workers is a thing of the past that just does not match the flexibility needs of modern businesses any more. But once employees lose their "own" desk, they are more likely to spend more time at mobile locations. In this case, mobile eWork is not only a driver behind new concepts of office space management, but can also result from these: both developments are mutually reinforcing.

Technological drivers include the developments in ICT, which have boosted time-space compression. In combination with progress in transport technology, these have dramatically reduced the time it takes to move humans, physical goods and information across distance. Harvey (1989) illustrated the concept with maps of the world that shrink over time proportionately to the increasing speed of transportation. The world of the 1960s then is about one-fiftieth the size of the world of the sixteenth century because jet aircraft can travel at about fifty times the speed of a sailing ship. Time-space compression decreases the costs for physical mobility, thereby inducing demand. Transportation costs have fallen continuously in recent years, most drastically for air transport.

Closely related to the above, socio-cultural drivers have caused increases in the demand for transport. A powerful process in this regard is what is called urban spread, which is a long-standing process that was set in motion by private car traffic and the telephone. In its course, population and businesses have been relocating away from city centres towards the urban fringes and towards major transport arteries (CSP 1999). Notwithstanding recent evidence that city centres are becoming more attractive again, urban spread is continuing with the same speed as ever, leading to more complex and diffuse patterns of commuting and business transport, and overall higher levels of individual transport. Other developments in society of relevance here include the growing numbers of dual income households with partners who work at distant locations and as a consequence have high mobility requirements. Moreover, increasing household incomes imply a higher level of personal mobility, for example holiday 
abroad several times per year, because demand for leisure travel has a very high income elasticity (OECD 2000).

\subsubsection{Physical and virtual mobility}

Having listed a number of the most important drivers of worker mobility, it is important to recall that in the world of work, physical mobility is not an end in itself. It serves economic interests and underlies considerations of (pecuniary) costs and benefits. In general, worker mobility is being utilised to achieve an optimal allocation of human capital in the production system. The costs involved in working in a mobile rather than fixed setting can be significant, as the chapter by Mark Perry and Jackie Brodie in this book lays out when discussing "mobilisation work". In general, human capital is today by far the least mobile of all production factors. Companies are, therefore, constantly seeking out alternatives to physical mobility in order to control costs while still enjoying the benefits from close interconnectedness with value chain partners and customers. One way of doing so, much discussed in the futurist literature, is to supplement ICT for physical mobility. An example would be to conduct a video-conference instead of calling persons for a face-to-face meeting, which implies physical travel. Other examples for virtual mobility include all kinds of computer supported collaborative work (CSCW). Complex documents such as construction drafts that used to be presented and discussed in meetings can be circulated and discussed through the Internet. Such forms of work are already quite wide-spread, as EU data from SIBIS indicates (see section 3.4.3 below).

While physical and virtual mobility serve similar purposes - namely to make work (products, inputs) available where it produces the highest added value at any given time - there is much evidence which suggests that both do in practice not so much substitute for each other as they are complementary: the more people interact with others through ICTs, the more likely they are to seek face-to-face interaction as well (Niles 1994, OECD 2000). One reason for this is that ICTs not only provide potential substitutes for physical travel, but they are at the same time also making mobile working much more efficient and effective than ever before. This is briefly outlined in the following section. 


\subsubsection{ICTs as drivers of mobile work}

ICTs play a powerful role as drivers of physically mobile work. For a discussion, it is useful to start looking at problems surrounding mobile work without ICTs.

Mobile work can cause a number of problems related to an interrupted communication flow between the mobile worker and colleagues, superiors and customers. Mobile workers who are co-operating with a fixed-location basis are separated from on-going business processes, resources, infrastructures and face-to-face communication opportunities. In a situation where a division of labour exists, the problem of assembling the results of work from different workers arises. Typical challenges that may arise from mobile work without ICTs are non-accessibility, that means mobile workers not or not fully reachable, unknown location, that means current location of the mobile worker is unknown; particularly important for emergency medical services and forwarding agencies, limited ability to carry resources, that means limited ability to transport and process information, limited resource access, that means lack of full access to databases, secretary services and other resources, and media breaks, that means detachment from on-going business processes causing media breaks between the fixed and the mobile part of the value chain (Schulte 1997).

ICTs may reduce these problems of mobile work significantly. In fact, many activities could not be accomplished on the move at all until ICTs enabled mobility. Writing documents and analysing data requiring a machine was not possible on journeys until portable computers were created to do such work while sitting in a train or in the premises of a distant customer enterprise. Other examples of the ways ICTs can facilitate, enable and support mobile work include:

- Swifter data processing: ICTs allow a more efficient way of data processing and, in an ideal case, data flows without media breaks in spite of different, partly mobile locations involved. Mobile devices for salespersons, for example, enables them to take new orders at the customers' site and enter them immediately into the central computer system. At the headquarters the order is then transferred to the company's computerbased order and logistic system in real time.

- Time saving: Instant data processing can also lead to considerable savings in throughput times, as business processes can be fully integrated regardless of the distance involved between parts of the value chain. This decreases the costs of mobility compared to static work environments. 
- Location independence: Mobile end devices allow instant communication when the need for it arises, independent of the location. Without a mobile phone, for example, persons working in the field would have to search for a public phone or ask clients to allow them to use their phone. Mobile computing devices also depend much less on fixed access to data networks than desktop equipment.

- Instant information retrieval: While on a journey, mobile telephony and online acess allows userd to retrieve information from company or public sources - including timetables, restaurant guides and hotel finders.

- Weight reduction: In many cases, ICTs reduce the weight of work material. For example, digitised files have made work locationally flexible which was bound to a single location before because of the need for instant access to archived data.

- Cost reduction: ICTs have played a vital role in pushing down travel costs per mile travelled - a long-term trend which has gained speed in recent decades. Computer networks are a central component of all modern travel systems, no matter whether on rail, road, water or in the air.

The advance of 3G and later generations of mobile networks will further strengthen these advantages by offering broadband connections, and all applications made possible by them, for mobile use.

\subsection{Conceptualising mobile eWork}

The term "eWork" has been promoted mainly by the European Commission (CEC 2003) to indicate a step onwards from previous notions of telework. From the research and practitioner literature, it appears that the ways in which eWork differs from the earlier concept of telework are: (a) while telework in the traditional sense is mostly focussing on individualised changes of work location, most prominently at home, eWork also includes remote work in shared office premises, such as call-centres and other remote back offices (Huws and O'Regan 2001); and (b) in addition to traditional telework, eWork is understood to also cover tele-collaboration, i.e. telemediated work forms carried out by workers located in traditional office environments, as in the case of virtual teams which stretch across the boundaries of single organisations (Eichmann et al. 2002). In order to distinguish between such tele-collaboration and traditional types of telework, it is useful to describe the latter as principal/agent relationships (see Eisenhardt 1989) to highlight the fact that they consist of a principal, i.e. 
somebody, such as a superior, who does not act directly but instead by giving incentives - such as money, career prospects - to other persons, and agents who carry out the work on their behalf. In collaboration, there is not necessarily any hierarchical relationship between co-workers, but rather a situation where two or more people work together to create or achieve the same thing (Hanhike and Gareis 2004). ${ }^{2}$

We define telemediation as the transfer of work inputs and/or outputs via data telecommunication links. Remoteness refers here to the physical distance between persons involved, either principal and agent or various collaborators. Any definition as in "remote work" either leaves much room for interpretation, or must appear rather arbitrary. Nevertheless, most often remote work is being (implicitly) defined as meaning different sites, locations and addresses. For example, telemediated work exchange between two establishments, even if they belong to the same organisation, should be considered eWork if they do not share the same address. On the other hand, co-located workers who nevertheless make extensive use of computer supported collaborative work should not count as eWorkers, because distance does not play any significant role in their case.

Work in this context is any type of gainful employment. We define collaboration in virtual teams as a group of individuals who (or: some of whom) are located remotely from each other and who work together to create or achieve the same thing, and in which interaction takes place exclusively or almost exclusively via telemediation (compare Lipnack and Stamps 1997). They can, but do not have to stretch across organisational boundaries.

A definition of eWork therefore should comprise any type of telemediated remote work and include the following types:

- individualised or shared-office based referring only to the physical workplace of the worker, not to the fact that they share an office with the principal or collaborators;

- collaborative work, that means tele-cooperation or virtual teams, or work which is performed in the context of principal-agent type relationships;

- work interaction which is inter-organisational, i.e. coordinated over the market such as in client/contractor relationships and freelance work, or

2 A more precise definition of tele-collaboration needs to address what kind of information is transmitted, and for what purpose. This can be operationalised by defining collaboration as being based on an explicit (e.g. written, but not necessary legally binding) agreement about common aims. 
work interaction which is intra-organisational, that means coordinated internally in organisations. ${ }^{3}$

Accordingly, Table 3.1 presents a typology of eWork, based on previous work by Huws and O'Regan (2001). The grey cells contain the main types of eWork, while the last line lists some types which do not fall in the eWork category.

Table 3.1. Typology of eWork

\begin{tabular}{|c|c|c|c|c|c|}
\hline & \multicolumn{4}{|c|}{ Coordination mechanism } \\
\hline & & \multicolumn{2}{|c|}{ Principal/agent } & \multicolumn{2}{|c|}{ Collaboration } \\
\hline & & $\begin{array}{c}\text { intra- } \\
\text { organisational }\end{array}$ & $\begin{array}{c}\text { inter- } \\
\text { organisational }\end{array}$ & $\begin{array}{c}\text { intra- } \\
\text { organisational }\end{array}$ & $\begin{array}{c}\text { inter- } \\
\text { organisational }\end{array}$ \\
\hline \multirow[b]{2}{*}{ 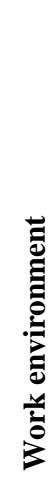 } & $\begin{array}{r}\text { Individualised } \\
\text { eWork } \\
\text { (away from of- } \\
\text { fice premises) }\end{array}$ & $\begin{array}{l}\text { Telework in } \\
\text { employment } \\
\text { relationships }\end{array}$ & $\begin{array}{l}\text { Freelance } \\
\text { telework }^{4}\end{array}$ & $\begin{array}{l}\text { Work in virtual } \\
\text { teams com- } \\
\text { posed of tele- } \\
\text { working } \\
\text { employees } \\
\text { from a single } \\
\text { company }\end{array}$ & $\begin{array}{l}\text { Work in virtual } \\
\text { teams made up } \\
\text { of teleworkers } \\
\text { from different } \\
\text { companies (or } \\
\text { self-employed) }\end{array}$ \\
\hline & $\begin{array}{r}\text { eWork on } \\
\text { shared office } \\
\text { premises }\end{array}$ & $\begin{array}{l}\text { eWork at other } \\
\text { site of same } \\
\text { company } \\
\text { (e.g. back of- } \\
\text { fices) }\end{array}$ & eOutsourcing & $\begin{array}{l}\text { Work in virtual } \\
\text { teams } \\
\text { composed of } \\
\text { employees } \\
\text { from a single } \\
\text { company }\end{array}$ & $\begin{array}{l}\text { Work in virtual } \\
\text { teams com- } \\
\text { posed of em- } \\
\text { ployees from } \\
\text { different com- } \\
\text { panies }\end{array}$ \\
\hline & $\begin{array}{r}\text { Non-eWork } \\
\text { (examples) }\end{array}$ & $\begin{array}{c}\text { Employed } \\
\text { agents } \\
\text { co-located with } \\
\text { principals }\end{array}$ & $\begin{array}{c}\text { Self-employed } \\
\text { co-located with } \\
\text { clients }\end{array}$ & $\begin{array}{l}\text { Work in co- } \\
\text { located teams } \\
\text { composed of } \\
\text { employees from } \\
\text { a single com- } \\
\text { pany }\end{array}$ & $\begin{array}{l}\text { Work in co- } \\
\text { located teams } \\
\text { composed of } \\
\text { employees from } \\
\text { different com- } \\
\text { panies }\end{array}$ \\
\hline
\end{tabular}

Source: based on Huws and O'Regan (2001); Hanhike and Gareis (2004).

Some of these types of eWork can also have a strong component of physical mobility, in which case they can be considered as mobile eWork.

${ }^{3}$ It should be noted here that this distinction has become less clear-cut in recent years, since many transactions inside of companies are nowadays managed very similarly than market transactions, e.g. in the case of individual profit centres which together make up a larger, often multi-national corporation.

${ }^{4}$ For persons who conduct the major part of their work through networked work environments, we can use Laubacher amd Malone's term "eLancer" (Laubacher and Malone 2001). 
This refers to individualised eWork only, since eWork on shared office premises is by definition stationary. For identifying mobile applications of eWork, we need to define mobile work more clearly.

According to Perry et al. (2001), mobile work activities involve "working at multiple (but stationary) locations, walking around a central location, travelling between locations, working in hotel rooms, on moving vehicles and in remote meeting rooms". However, for the purpose of this chapter we exclude mobile work of the type "walking around a central location" since it does not comply with our criterion of remoteness (see above). In order to distinguish mobile workers from non-mobile workers, one may also need to add the temporal dimension, i.e. set a lower threshold of time spent in mobile work activities for a worker to be considered as mobile. Other important dimensions include the mode of working, i.e. to what extent the mobile activity is supported by technology and how much the mobile worker is integrated in company information networks, and the purpose of worker mobility (Heinonen 2004). While the former concerns the distinction between mobile work and mobile eWork, the latter is linked to the question whether mobility requirements are work-related or not ${ }^{5}$.

\subsection{Mobile work and mobile eWork today}

This section presents some quantitative evidence about the spread of different types of mobile eWork in Europe. 3.4.1 contains data on the spread of mobile work in general, while 3.4.2 discusses the diffusion of mobile eWork and presents an analysis of the development of all individualised types of eWork in recent years. Albeit the amount of statistics available is very limited, there is evidence which suggests that mobile eWork is growing in significance in comparison to other types such as alternating, homebased telework. 3.4.3 then presents early findings on the diffusion of types of tele-collaboration, that means "virtually mobile" eWork.

\subsubsection{Mobile work}

SIBIS defined mobile workers as those who "spend some paid working time away from their home and away from their main place of work, e.g.

5 In this respect, Bell (2002) distinguishes between production- and consumptionrelated mobility. 
on business trips, in the field, travelling or on customer's premises" at least once per month. High-intensity mobile workers are those who do so for 10 hours or more per week. In both cases work commutes are not included.

According to the data from SIBIS, 28\% of EU15 workers spent some paid working time doing mobile work in 2002. The number of highintensity mobile workers was roughly half of this (15\%).

The share of mobile workers differs considerably between countries (see Table 3.3). In the EU15 the range is from $46 \%$ in the Netherlands and $45 \%$ in Finland to only $8 \%$ in Portugal. There appears to be a North-South divide with above-average levels of mobile work in Finland and Sweden and below-average levels in Greece, Italy, Portugal and Spain. In the $10 \mathrm{New}$ Member States and Acceding Countries covered by the SIBIS data, average shares of mobile workers are lower, although some of the smaller countries do have figures which are similar to the EU15 average; this applies to Slovenia, the Baltic countries, and Slovakia.

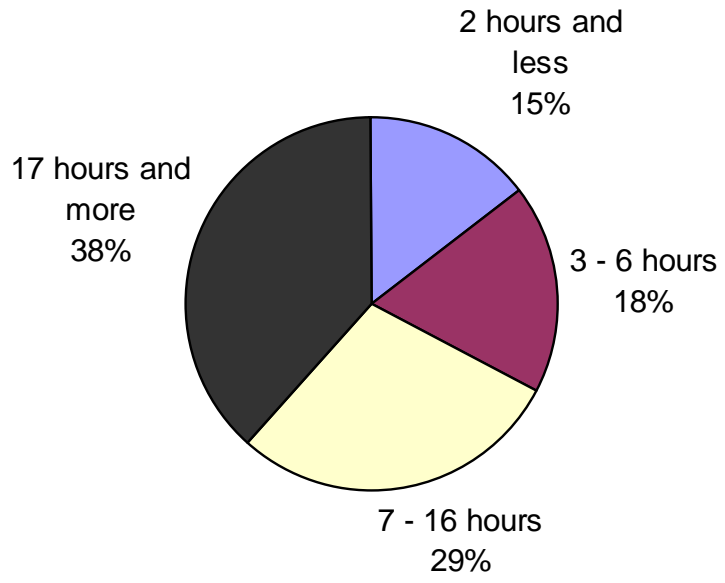

Fig. 1. Time spent on the move by mobile workers in $\%^{6}$

Regarding the intensity of working at mobile locations, mobile workers were grouped into quartiles of 2 and less hours, 3 to 6 hours, 7 to 16 hours and more than 16 hours. According to the results, many mobile workers spend a large share of their working time away from home or their main place of work. In the EU15, 15\% of mobile workers work two and less paid working hours per week away from home and the main place of work,

${ }^{6}$ Unweighted average for EU15, CH and USA. Source: SIBIS General Population Survey 2002, empirica. Base: All mobile workers $(n=1277)$ 
18\% between 3 and 6 hours, 29\% between 7 and 16 hours, and 38\% work 17 hours and more at mobile locations (see Fig. 1).

Closer analysis of the data using logistic regression analysis (see Annex) sheds some light on the factors which determine the likelihood of a worker practising mobile work:

- Education: There is a clear correlation between the likelihoood to do mobile work and educational attainment, measured by the age at which initial full-time education was finished. A post secondary degree increases the likelihood of doing mobile work by $236 \%$ as compared to workers with only basic education; a higher secondary does so by $132 \%$.

- Occupation: When broadly distinguishing between blue collar, white collar and managerial or professional workers, we find that the latter two are significantly more likely to do mobile work (106\% and $227 \%$, respectively).

- Employment status: $26 \%$ of paid employees do mobile work, while $42 \%$ of self-employed belong to this group. However, when controlling for other factors such as occupation, educational attainment, gender and country, we find that workers with a contract of employment are $68 \%$ more likely than the self-employed to do mobile work. The fact that the self-employed tend to be more mobile than employees does reflect, therefore, mainly the type of work they are involved in rather than employment status as such.

- Full-time or part-time employment: 31\% of full-time employees do mobile work, while the respective value for part-time employees is only $18 \%$. When controlling for third factors, however, no significant effect of working hours can be detected. The same applies for type of contract (unlimited versus temporary).

- Public or private sector: The differences between mobile work practice in public or non-profit organisations (26\% of the employees) and private organisations (30\%) are not large. After controlling for third factors, we find that workers in the private sector are $25 \%$ more likely to do mobile work compared to public sector workers.

- Company size class: Although the share of mobile workers is highest in large establishments with more than 250 employees (30\%), all in all differences by size class are negligible.

- Gender: Of all male employees, 38\% reported to do mobile work, while the figure is only $18 \%$ for female workers. This is partly caused by the fact that women are less represented in management positions and among the self-employed than men. Still, after controlling for these and 
other factors, women remain $67 \%$ less likely to do mobile work then men.

- Age: The effect of age on the likelihood to be engaged in mobile work practice is insignificant.

- Country: As stated above (see also Table 3.3), there are huge differences in the number of mobile workers across EU countries. It can be assumed, however, that these are partly explained by third factors such as sectoral structure, educational attainment, the share of white-collar workers etc. Multivariate analysis allows us to single out those Member States in which country-specific factors seem to account for a high or low share of mobile workers. Taking as a reference country France, which has a share of mobile workers which is close to the EU25 average, Finland, the Netherlands, Sweden and Slovenia have a significantly higher incidence of mobile work, while workers in Romania, Portugal, Poland, Bulgaria, Hungary, Spain, Luxembourg and the Czech Republic are significantly less likely to work in a mobile setting.

As this analysis shows, there are a number of factors which have a considerable influence on the odds of doing mobile work. Most obviously, occupational category and educational attainment play a dominant role. Gender, employment status, and in many cases the country also significantly affect the likelihood of doing mobile work. This has a number of implications for policy as well as research, which are discussed in section 3.5 .

\subsubsection{Mobile eWork}

Mobile eWork is defined as high-intensity mobile work in the course of which an online connection to the Internet and/or to company computer systems is being used. $4 \%$ of the EU15 work force are mobile eWorkers. Switzerland is the leader here among the countries in the survey, followed by Finland, the USA, Germany and Italy. The penetration in Eastern and Central Europe is again much lower with an average of about 1\%, although Estonia and Slovenia have impressively high figures. ${ }^{7}$

The main purposes of mobile eWorkers to use online connections is sending and reading e-mail (92\%), but three quarters each also browse the Internet and connect to their company's internal computer system. O'Hara et al. (2002) found in an empirical study of a group of mobile eWorkers

7 Data from Lithuania is missing for this indicator. 
that e-mail was used less for outgoing than for incoming communication, and it was much less used for managing urgent situations than the mobile phone. Furthermore, e-mail was only used by those survey participants who stayed overnight away from home. The typical scenario was to check e-mails at a hotel.

Table 3.2. Mobile eWork (in \%, EU15)

\begin{tabular}{lr}
\hline Mobile eWorkers (use computer connections when travelling) & 4.0 \\
\hline thereof (multiple response): Purpose & \\
for accessing the Internet & 73.4 \\
for sending or reading e-mails & 92.4 \\
for connecting to their company's internal computer system & 72.4 \\
thereof (multiple response): Location & \\
hotel, conference site or similar location & 68.7 \\
$\quad$ another company's premises & 52.0 \\
$\quad$ Internet café or commercial teleservice centre & 5.4 \\
$\quad$ on the move using mobile device for data transfer & 37.0 \\
Other high-intensity mobile workers & 11.4 \\
Low-intensity or non-mobile workers & 81.8 \\
DK & 2.8 \\
Total & 100.0 \\
\hline
\end{tabular}

Base: All persons employed (N=5,100); weighted by EU15 population. Data source: SIBIS 2002, GPS.

Table 3.2 also presents the means by which workers connect to electronic communication channels. One potential access point are teleservice centres, which offer travellers a temporary workplace equipped with PC, Internet access, printer, fax etc. Such service providers are emerging at the nodes of international traffic networks, that means at central locations in large cities as well as airports. They may contribute to making mobile work attractive for more and more travellers. However, currently only 5\% of all mobile eWorkers make use of telework centres, whereas most choose the hotel room or conference site, another company's premises a similar location for going online. More than a third use truly mobile technology, i.e. data transfer via mobile devices, for the purpose. 
Table 3.3. Spread of mobile work and mobile eWork (in \% of employment)

\begin{tabular}{|c|c|c|c|c|}
\hline & $\begin{array}{l}\text { All mobile } \\
\text { workers }\end{array}$ & $\begin{array}{c}\text { High intensity } \\
\text { mobile } \\
\text { workers }\end{array}$ & $\begin{array}{c}\text { Mobile } \\
\text { eWorkers }\end{array}$ & $\begin{array}{c}\text { Tele- } \\
\text { cooperation }\end{array}$ \\
\hline Austria & 22.4 & 13.6 & 3.7 & 35.9 \\
\hline Belgium & 25.7 & 12.5 & 2.4 & 37.5 \\
\hline Denmark & 26.8 & 14.0 & 2.7 & 55.8 \\
\hline Finland & 44.5 & 19.7 & 6.2 & 55.5 \\
\hline France & 25.7 & 15.5 & 2.1 & 25.9 \\
\hline Germany & 31.8 & 16.3 & 5.7 & 45.8 \\
\hline Greece & 21.5 & 15.2 & 3.5 & 12.6 \\
\hline Ireland & 30.3 & 19.7 & 4.2 & 37.3 \\
\hline Italy & 24.8 & 14.1 & 5.5 & 35.2 \\
\hline Luxembourg & 20.7 & 6.8 & 1.5 & 42.4 \\
\hline Netherlands & 45.5 & 19.6 & 4.1 & 46.7 \\
\hline Portugal & 8.4 & 4.3 & 0.3 & 9.3 \\
\hline Spain & 17.4 & 9.1 & 0.8 & 21.2 \\
\hline Sweden & 39.8 & 19.4 & 4.9 & 52.3 \\
\hline U.K. & 32.8 & 18.9 & 4.7 & 48.9 \\
\hline EU 15 & 28.4 & 15.4 & 4.0 & 37.8 \\
\hline USA & 32.1 & 19.0 & 5.9 & 53.2 \\
\hline Bulgaria & 17.5 & 11.8 & 1.0 & 15.6 \\
\hline Czech rep. & 20.9 & 14.6 & 2.1 & 20.7 \\
\hline Estonia & 26.5 & 13.7 & 3.9 & 31.3 \\
\hline Hungary & 19.3 & 16.8 & 0.9 & 12.7 \\
\hline Latvia & 24.1 & 14.9 & 2.4 & 20.3 \\
\hline Lithuania & 24.8 & 16.9 & n.a. & 21.1 \\
\hline Poland & 12.3 & 8.5 & 1.0 & 16.8 \\
\hline Romania & 6.1 & 5.3 & 0.6 & 8.5 \\
\hline Slovakia & 24.9 & 16.3 & 1.8 & 14.4 \\
\hline Slovenia & 34.8 & 20.9 & 3.0 & 31.9 \\
\hline NAS 10 & 15.8 & 11.2 & 1.2 & 16.0 \\
\hline
\end{tabular}

Base: All persons employed (N=5,901), weighted; averages weighted by EU15/ NAS10 population. Source: SIBIS 2002/2003, GPS.

The share of mobile eWorkers among overall EU15 employment has grown from $1.5 \%$ to $4 \%$ in the course of only three years (1999-2002) ${ }^{8}$. This is likely to benefit employers, in particular, as the efficiency of business process increases because of more continuous communication flows (Julstrud 1998, Gareis 2003). This increase can be explained by a number

81999 data stems from surveys conducted in the context of another EU research project (ECATT). which made use of very similar methodology including survey questionnaires, see CEC 2000. 
of factors, as outlined in section 3.2. There is much evidence that mobile computing technology and online access are being increasingly used for work. According to the Working Life Barometer 2002 in Finland, a forerunner country with respect to mobile phone usage, almost $40 \%$ of wage and salary earners have been carrying out work tasks in their leisure time by means of a connection to their employer via mobile phone or ICT network (Ylöstalo 2003). The boundaries between work at a central office, on the road or in the field, at customer's premises, at teleservice centres and at home are likely to further disappear step by step. The same applies, it seems, to the boundaries between working time and leisure time (Voß 1998).

Table 3.4. Development of individualised telework in \% of all persons employed (weighted averages) in EU15

\begin{tabular}{lcc}
\hline Type & \multicolumn{2}{c}{ EU15 } \\
\hline & 1999 & 2002 \\
Home-based telework (at least 1 day/week) & 2.0 & 2.1 \\
Supplementary home-based telework & 2.0 & 5.3 \\
Mobile eWork (SIBIS definition) & 1.5 & 4.0 \\
Freelance telework in SOHOs & 0.9 & 3.4 \\
All individualised telework (excl. overlaps) & 6.0 & 13.0 \\
\hline
\end{tabular}

Base: All persons employed; weighted by EU15 population. Data source: Empirica 1999, 2002.

While the number of mobile eWorkers appears to be growing rapidly, the same is not true for traditional, home-based telework as long as this takes up at least one full working day per week, which implies that some form of agreement between employee and supervisor/employer exists about the issue. The share of such home-based teleworkers has remained stagnant over the period 1999-2002 in the EU15.

Permanent telework by persons with a contract of employment is so rare in Europe that it could not be measured in a statistically significant way using the SIBIS sample of $~ 12,000$ interviews in the EU15. Among the selfemployed, permanently working from home is more wide-spread, for obvious reasons. It has become more and more obvious in recent years that permanently teleworking at home is in most cases not sustainable with regard to psychosocial (Huuhtanen 1997) and economic factors (Gareis 1999). The FAMILIES project (Cullen et al. 2003) has reported evidence from a major Danish company according to which telework's mid-term effect on productivity was slightly negative in case of permanent or nearpermanent telework, while it was very positive for alternating teleworkers. 
The reasons given for the poor performance of permanent teleworkers refer to the lack of social and informal interaction with colleagues, which resulted in a loss of motivation and insufficient access to intra-company information flows.

But while permanent teleworking at home remains an exotic phenomenon, and alternating home-based telework is hardly increasing at all, supplementary home-based telework -that means working for less than one full day per week at home - is on the rise (see Table 3.4). In 2002, there were more than two and a half times more supplementary teleworkers in the EU15 than three years before. ${ }^{9}$

These findings have been confirmed by research carried out at the national level (USA: ILO, quoted in Di Martino 2001:30; UK: Di Martino 2001:37; Finland: Statistics Finland 2003). They suggest that there is a shift among home-based teleworkers towards less time spent at home. Obviously, the progress in the availability of cheap and powerful remote access technology has not led to workers spending more and more time working at home, but rather to more and more workers spending only a fraction of their weekly working time at home. This points towards a greater flexibility in the use of individual working locations, but at the possible expense of some of the traditional advantages ascribed to telecommuting such as savings on miles travelled.

Freelance teleworkers in SOHOs are self-employed persons who work from home, on the same grounds as their home or with their home as their base, and use online ICTs for interaction with their clients. The survey showed that 3\% of EU employment belongs to this group, which translates into $21 \%$ off all self-employed. The share of teleworkers is therefore considerably higher among the self-employed than among workers with a contract of employment. Telework seems to be on the way to becoming the standard working mode for the majority of freelancers. Between 1999 and 2002 , the number of SOHO-based teleworkers has grown from $1 \%$ to more than $3 \%$ as a result of annual growth rates averaging more than $50 \%$. The candidate countries (average 2\%) are somewhat behind the EU, but to a lesser extent than it is the case for the other types of telework.

It has been suggested that to categorise teleworkers as either "homebased" or "mobile" distracts from the fact that many teleworkers spend their working time at a number of different locations, among which the

9 It is important to note here that this definition of supplementary home-based eWork (and all related figures presented in this paper) requires that paid working time is spent at remote locations. Definitions which also include unpaid work-related activities quickly arrive at figures of between a quarter and half of all workers doing work at home (Di Martino 2001:33; Ylöstalo 2003:85). 
home might be only one option. This trend has obviously been enabled by mobile office technology, which has liberated work from being bound to a particular space and time. For this phenomenon, the term "multi-locational telework" has been invented (CEC 2003; Gareis et al. 2004b). It implies that persons work wherever it suits their work tasks, business schedule, and/or lifestyle.

Table 3.5. Multi-locational telework - working locations

\begin{tabular}{l|c|c|c|c|c}
\hline \multicolumn{1}{c|}{ Base $\rightarrow$} & $\begin{array}{c}\text { (a) } \\
\text { at home or } \\
\text { the same } \\
\text { grounds }\end{array}$ & $\begin{array}{c}\text { (b) } \\
\text { on another } \\
\text { site of em- } \\
\text { ployer }\end{array}$ & $\begin{array}{c}\text { (c) } \\
\text { at custom- } \\
\text { ers/ clients }\end{array}$ & $\begin{array}{c}\text { (d) } \\
\text { at a hotel/ } \\
\text { meeting } \\
\text { venue }\end{array}$ & $\begin{array}{c}\text { (e) } \\
\text { on the } \\
\text { move }\end{array}$ \\
\hline $\begin{array}{l}\text { at home or } \\
\text { the same } \\
\text { grounds }\end{array}$ & 100.0 & 40.4 & 42.2 & 39.1 & 42.5 \\
\hline $\begin{array}{l}\text { on another } \\
\text { site of em- } \\
\text { ployer }\end{array}$ & 11.5 & 100.0 & 52.5 & 57.4 & 55.6 \\
\hline $\begin{array}{l}\text { at customers/ } \\
\text { clients }\end{array}$ & 17.4 & 76.0 & 100.0 & 64.6 & 71.9 \\
\hline $\begin{array}{l}\text { at a hotel/ } \\
\text { meeting } \\
\text { venue }\end{array}$ & 9.2 & 47.4 & 36.9 & 100.0 & 50.1 \\
\hline \begin{tabular}{l} 
on the move \\
\hline
\end{tabular} & 14.2 & 65.2 & 58.3 & 71.0 & 100.0 \\
\hline
\end{tabular}

Base: all multi-locational workers. Data source: BISER RPS 2003, weighted.

Data from the BISER survey can be used to assess in detail how much time eWorkers have spent at each of five "atypical” working locations (Gareis et al. 2004b). Table 3.5 shows the share of those teleworking from one of these locations (columns) who also do telework at each of the other locations (rows). For example, of persons teleworking from the home (a) $11.5 \%$ also work at a second location of their employer and use online connections to stay in contact when doing so. Another example: $42.5 \%$ of those who telework from mobile locations (e) also spend time teleworking from home.

The figures in the table provide evidence that multi-locational work has indeed become a normal way of working for a considerable share of total employment. Only persons teleworking from home are unlikely to spend time teleworking from other locations. The reason for this might be that the equipment in home offices is often fixed in space, i.e. cannot be used for teleworking from other locations, such as desktop, home-bound Inter- 
net access. On the other hand, once workers have access to mobile computing equipment, they seem to choose any of a number of different working locations, including a second location of their employer, the premises of customers or clients, hotels and meeting venues, and temporary locations while travelling.

\subsubsection{Tele-collaboration: "virtually mobile eWork"}

SIBIS collected data on the extent to which the EU labour force is involved in tele-cooperation already. For this, a very basic definition was used which included everybody who regularly uses e-mail or the Internet to communicate with work contacts located at other business sites, either in other organisations or at other sites of the same organisation.

Table 3.3 shows that more than every third worker in the EU15 is involved in regular tele-cooperation, if defined in that way - about three times as many as there are teleworkers.

\subsection{Conclusions and Outlook}

This chapter has discussed a conceptual framework for eWork, which attempts to include established forms such as home-based telework as well as types of ICT-enabled work which have entered the debate only recently, such as locationally flexible work taking place in traditional office environments, and work relationships which are collaborative rather than following a principal-agent pattern. We think that progress in the conceptual underpinning of research on ICT-enabled work forms is strongly needed because

- much research suggests that traditional (home-based) teleworking is unlikely to ever achieve the significance for the labour market which was predicted only a few years ago;

- it is increasingly acknowledged that networked work environments which make extensive use of ICTs for interconnecting workplaces across space and time, but do not necessarily involve a relocation of physical workplaces from central offices - play a key role for economic competitiveness.

The chapter has also tried to contribute to a better understanding of the relationship between physical mobility and applications of ICTs for work, 
namely in the form of ICT-supported environments for mobile work, i.e. mobile eWork. While general opinion still tends to equate the application of ICTs in work settings with a substitution for physical mobility, ICTs also give powerful support to mobile working, thereby allowing for closer contact with customers and value chain partners, more efficient use of spare time during travel, and abolishment of traditional disadvantages of work mobility such as disconnection from communication networks. Since there are a number of powerful drivers which increase the demand for work which is physically mobile, mobile eWork can be expected to keep growing rapidly over the coming years.

This is not meant to suggest that what may be called "virtually mobile work", i.e. collaboration through online data networks such as the Internet, would be insignificant. Quite the contrary, tele-collaboration is starting to affect an increasing share of the EU workforce, as witnessed by the 2002/2003 data from SIBIS (see Table 3.3). According to the definition of SIBIS, already every third worker in the EU15 is involved in telecollaboration, and 16\% in the New Member States of Central and Eastern Europe. These figures are based on a simplified definition of collaboration. More research is clearly needed in order to develop and apply more advanced indicators which are able to distinguish between different degrees and intensities of collaboration, and differences in the significance of online tools for collaborative work.

Such research will enable us to better understand the size and shape of the change which is currently ongoing in the world of work. For policymaking, it will be essential to establish quantitative evidence about the effect of eWork on key variables of competitiveness such as productivity, innovativeness, and time-to-market. While recent research has provided insight into impacts of traditional telework on, for example, sustainable development (see e.g. Schäfer 2004), only little is known about the effects of "virtual mobile work". This is, of course, mainly due to the elusive nature of these applications of ICT. This must not, however, deter us from trying to establish more evidence.

In addition, policy-makers need more information about the barriers and facilitators of eWork applications, and these need to distinguish carefully between developments which can be assumed to be compatible with current policy goals, and developments which are in danger of undermining the effectiveness of policy-making. Gareis et al. (2004a) have found indicative evidence which suggests that take-up of eWork as well as telecollaboration is negatively correlated with the degree of employment protection legislation, and also with an index of risk aversion at national level. Such evidence alone, however, does not give us any indication whether eWork is being applied in ways which optimally exploit potential benefits 
for society, or not. Against this background, research on the economic, ecological and social sustainability of eWork applications appears to be of highest relevance.

\section{References}

Bell, M (2002) Measuring Circulation in Developed Countries. ICPG 2002

Commission of the European Communities (eds)(2000) Benchmarking Telework and E-Commerce in Europe. (ECATT Final Report) Commission of the European Communities, Brussels

Commission of the European Communities (eds)(2003) eWork, Competitiveness, Productivity and Sustainable Development. (Proceedings of the 9th European Assembly on Telework, Paris, September 2002) CD-ROM

Committee on Spatial Development (CSP)(1999) European Spatial Development Perspective - Towards Balanced and Sustainable Development of the Territory of the EU. Office for Official Publications of the European Communities, Luxembourg

Cullen K, Kordey N, Schmidt L, Gaboardi E (2003) Work and Family in the eWork Era. IOS Press, Amsterdam et al.

Davidow WH, Malone MS (1992) The Virtual Corporation - Structuring and Revitalizing the Corporation for the 21st Century. HarperCollins, New York.

Dicken, P (2003) Global Shift, $3^{\text {rd }}$ edition. Sage, London

Di Martino, V (2001) The High Road to Teleworking. International Labour Organization, Geneva

eBusiness Watch (2003) The European e-Business Report 2003, 2nd Synthesis Report. Commission of the European Communities, Brussels

Eichmann H, Saupe B, Schwarz-Wölzl, M (2002) Critical Issues Pertaining to the Code of Practice for Global E-work (Project document, Centre for Social Innovation, Vienna).

Eisenhardt KM (1989) Agency Theory: An Assessment and Review. Academy of Management Review 14(1) 57-74

Ellen, I.G., and Hempstead, K. (2002) Telecommuting and the Demand for Urban Living: A Preliminary Look at White-Collar Workers. Urban Studies 39(4): 749-766

Empirica (2002) Work, employment and skills, SIBIS Topic Report no 5. Commission of the European Communities, Brussels

European Foundation for the Improvement of Living and Working Conditions (2002) Third Working Conditions Survey. Office for Official Publication of the European Communities, Luxembourg

Gareis, K (1999) Benchmarking Progress on Telework and Other New Ways of Working in Europe. In: Proceedings of the Fourth International Workshop on Telework, Tokio, August 31st - September 3rd 1999, n.p. 
Gareis, K (2003) Home-based vs. Mobile Telework. The Interrelationship Between Different Types of Telework. In: Rapp B, Jackson P (eds) Organisation and Work Beyond 2000. Physica, Heidelberg New York, pp 171-185

Gareis K, Hüsing T, Mentrup A (2004a) What Drives eWork? An Exploration into Determinants of eWork Uptake in Europe. Paper presented at the $9^{\text {th }}$ International Telework Workshop, Heraklion, Greece, September 6-9

Gareis K, Kordey N, Müller S (2004b) BISER Domain Report No.7: Work in the Information Society. Retrieved 25 April 2005 (URL: www.bisereu.com/results.htm)

Hanhike T, Gareis K (2004) Modelling eWork - Towards a Better Understanding of Information Technology's Impact on Workplaces and Work Locations. Paper presented at the 22nd Annual International Labour Process Conference, Amsterdam, 5-7 April

Harvey D (1989) The Condition of Postmodernity. Blackwell, Oxford.

Heinonen S (2004) Mobile Telework at the Crossroads of Social, Environmental and Cultural Challenges. Paper presented at the $9^{\text {th }}$ International Telework Workshop, Heraklion, Greece, September 6-9

Huws U, O'Regan S (2001) eWork in Europe: The EMERGENCE 18-Country Employer Survey. IES Report No. 380, Institute for Employment Studies, Brighton

Julstrud TE (1998) Combinations and Tracks: An Investigation of the Relationship Between Homework and Mobile Work. In: Suomi R et al. (eds) Telework Environments, Proceedings of the Third International Workshop on Telework. TUCS General Publication, no. 5, pp 148-163

Lilischkis S (2003) More Yo-yos, Pendulums and Nomads: Trends of Mobile and Multi-location Work in the Information Society. STAR Issue Report no. 36, Databank, Milano

Lilischkis S, Meyer I (2003) Mobile and Multi-location Work in the European Union - Empirical Evidence from Selected Surveys. STAR Issue Report no. 37, Databank, Milano

Massey D, Meegan R (1979) The Anatomy of Job Loss: The How, Why and Where of Employment Decline. Methuen, London

Niles, JS (1994) Beyond Telecommuting: A New Paradigm for the Effect of Telecommunications on Travel. Washington

Nurmela J, Ylitalo M (2003) Tietoyhteiskunnan kehkeytyminen, suomalaisten tietoyhteiskuntavalmiuksien ja - asenteiden muutos 1996-2002. Tilastokeskus Katsaukseia 3/2003, Statistics Finland, Helsinki

OECD, Austrian Federal Ministry for Agriculture, Forestry, Environment and Water Management (2000) Environmentally Sustainable Transport - Futures, Strategies and Best Practice. OECD, Paris.

O’Hara K, Perry M, Sellen A, Brown B (2002) Exploring the Relationship between Mobile Phone and Document Activity During Business Travel. In: Brown B, Green N, Harper R (eds) Wireless world. Social and Interactional Aspects of the Mobile Age, Springer, London, pp 180-194

Perry M et al. (2001) Dealing with Mobility: Understanding Access Anytime, Anywhere. ACM Transactions on Computer-Human Interaction 8(4) 323-347 
Schäfer RA (2004) Ökologische Beurteilung von Telearbeit - Konzeption und Realisierung eines Bewertungsmodells of Basis einer Verhaltensbilanz. Shaker, Aachen

Schulte BA (1997) Organisation mobiler Arbeit: der Einfluss von IuKTechnologien. Gabler, Wiesbaden

Valenduc G et al. (2000) Flexible Work Practices and Communication Technology. (Final Report of the FLEXCOT project), Commission of the European Communities, Brussels

Voß G (1998) Entgrenzte Arbeit und entgrenzte Arbeitskraft. Eine subjektorientierte Interpretation des Wandels der Arbeit. Mitteilungen aus der Arbeitsmarkt- und Berufsforschung 31(3) 473-487

Ylöstalo P (2003) Working Life Barometer October 2002. Työpoliittinen tutkimus no 250, Ministry of Labour, Helsinki 


\section{Statistical Annex}

\section{Analysis of SIBIS data}

As we deal mainly with non-metric variables, it is not useful to apply a linear regression model since no linear association can be expected. For our purpose, logistic regression is most appropriate. The logistic regression model is simply a non-linear transformation of the linear regression. For a case with two variables, the logit model is described as:

$\ln \left(\frac{p_{i}}{1-p_{i}}\right)=a_{1}+b x_{i}$

whereby:

In is the is the natural logarithm, $\log _{\text {exp }}$, where exp=2.71828...,

$p \quad$ is the probability that the event $\mathrm{Y}$ occurs, $\mathrm{p}(\mathrm{Y}=1)$,

$\frac{p_{i}}{1-p_{i}}$ is the "odds ratio", i.e. the probability of the event divided by the probability of the non-event,



The logistic distribution is an S-shaped distribution function which is similar to the standard-normal distribution (which results in a probit regression model) but easier to work with in most applications (the probabilities are easier to calculate). The logit distribution constrains the estimated probabilities to range from 0 to 1 . The dependent variable can be dichotomous and nominal (i.e. discrete not continuous).

To analyse the impact of different demographic, socio-economic and work related variables on the uptake of mobile work, we use the binary logistic regression procedure in SPSS. The variables included in the calculation are mostly non-metric variables. In fact, the dependent mobile work variable selected for the analysis is nominally scaled and dichotomous, which is one constraint for the chosen statistic model. The independent variables are of interval level or categorical, one is metric scaled. 
For interpretation we use the effect coefficient exp(b) which is the effect of the independent variable on the odds ratio. The last column of Table 3.6 displays the increase/decrease of the odds ratio as percentages.

Table 3.6. Determinants of incidence of mobile work (logistic regression, Exp(b))

\begin{tabular}{|c|c|c|}
\hline & \multicolumn{2}{|c|}{ Mobile work } \\
\hline & $\operatorname{Exp}(b)$ & in $\%$ \\
\hline \multicolumn{3}{|l|}{ Gender (reference: male) } \\
\hline female & $0.334 * *$ & -67 \\
\hline \multicolumn{3}{|l|}{ Age class (ref.: 14-24) } \\
\hline $25-34$ & 1.126 & 13 \\
\hline $35-49$ & 1.078 & 8 \\
\hline $50+$ & 1.024 & 2 \\
\hline \multicolumn{3}{|l|}{ Educational attainment (ref.: none and basic) } \\
\hline low secondary & $1.506^{*}$ & 51 \\
\hline high secondary & $2.317 * *$ & 132 \\
\hline post secondary & $3.364 * *$ & 236 \\
\hline \multicolumn{3}{|l|}{ Occupation (ref.: blue collar) } \\
\hline white collar & $2.065 * *$ & 106 \\
\hline managerial or professional & $3.267 * *$ & 227 \\
\hline \multicolumn{3}{|l|}{ Employment contract (ref.: self-employed) } \\
\hline with employment contract & $1.683 * *$ & 68 \\
\hline \multicolumn{3}{|l|}{ Working hours (reference: part-time) } \\
\hline full-time & 1.166 & 17 \\
\hline \multicolumn{3}{|l|}{ Type of contract (reference: fixed term) } \\
\hline \multicolumn{3}{|l|}{ Company size class (ref.: 50-249) } \\
\hline $0-49$ & 1.121 & 12 \\
\hline $250+$ & 1.113 & 11 \\
\hline \multicolumn{3}{|l|}{ Sector (ref.: public and non-profit sector) } \\
\hline \multicolumn{2}{|l|}{ Long standing illness (ref.: long standing illness) } & -10 \\
\hline \multicolumn{3}{|l|}{ Size of residential locality (ref.: small city/village) } \\
\hline city & 1.032 & 0 \\
\hline big city & 1.096 & 10 \\
\hline
\end{tabular}


Table 3.7. (cont.)

\begin{tabular}{|c|c|c|}
\hline & \multicolumn{2}{|c|}{ Mobile work } \\
\hline & $\operatorname{Exp}(b)$ & in $\%$ \\
\hline \multicolumn{3}{|c|}{ Country (ref.: France) } \\
\hline Austria & 0.802 & -20 \\
\hline Belgium & 0.737 & 0 \\
\hline Germany & 1.242 & 24 \\
\hline Denmark & 0.870 & -13 \\
\hline Finland & $1.943 * *$ & 94 \\
\hline Greece & $0.495 * *$ & 0 \\
\hline Ireland & 1.003 & 0 \\
\hline Italy & 0.784 & -22 \\
\hline Luxembourg & $0.614^{*}$ & -39 \\
\hline Netherlands & $1.653 * *$ & 65 \\
\hline Portugal & $0.227 * *$ & -77 \\
\hline Spain & $0.570 * *$ & -43 \\
\hline Sweden & $1.515^{*}$ & 52 \\
\hline Switzerland & 1.011 & 1 \\
\hline UK & 1.264 & 26 \\
\hline USA & 0.875 & -12 \\
\hline Bulgaria & $0.473 * *$ & -53 \\
\hline Czech Republic & $0.707 *$ & -29 \\
\hline Estonia & 0.879 & -12 \\
\hline Hungary & $0.534 * *$ & -47 \\
\hline Latvia & 0.820 & -18 \\
\hline Lithuania & 0.729 & -27 \\
\hline Poland & $0.366 * *$ & -63 \\
\hline Romania & $0.138 * *$ & -86 \\
\hline Slovakia & 0.928 & -7 \\
\hline Slovenia & $1.453^{*}$ & 45 \\
\hline Constant (b) & $0.008 * *$ & -99 \\
\hline
\end{tabular}

